\title{
Keefektifan Konsentrasi dan Jenis Pelarut Tepung Umbi Teki (Cyperus rotundus L.) sebagai Bioherbisida Pratumbuh untuk Pengendalian Gulma Asystasia gangetica (L.) T. Anderson
}

\author{
The Effectiveness of Concentration and Solvent Type of Purple Nutsedge Tubers Flour (Cyperus \\ rotundus L.) as Pre-emergence Bio-herbicide for Asystasia gangetica (L.) T. Anderson Weed Control
}

\author{
Dyana Chairannisa dan M.A. Chozin*
}

\author{
Departemen Agronomi dan Hortikultura, Fakultas Pertanian, Institut Pertanian Bogor \\ (Bogor Agricultural University), Jalan Meranti, Kampus IPB Darmaga, Bogor 16680,Indonesia \\ Telp.\&Faks.62-251-8629353 e-mail agronipb@indo.net.id \\ *Penulis untuk korespondensi : ma_chozin@yahoo.com
}

Disetujui 14 Mei 2018 / Published online 21 Mei 2018

\begin{abstract}
Cyperus rotundus is a weed species that can be potentially applied as pre-emergence bio-herbicide. The metabolites content of Cyperus rotundus are mostly found in the tuber. This study aimed to determine the effectiveness of nutsedge tuber (Cyperus rotundus) as bioherbicide in suppressing seed germination of Asystasia gangetica, and to know the concentration and solvent type of Cyperus rotundus tuber flour in suppressing of Asystasia gangetica. The experiment was conducted in May 2016 until November 2016. This research consisted of 2 experiments. The first experiment was the test of Cyperus rotundus tuber flour extract on germination Asystasia gangetica using top of paper methods. The second experiment was the test of Cyperus rotundus tuber flour extract on germination Asystasia gangetica using soil material. The first and second experiment were using a factorial completely randomized design. The treatments were consisted of two kinds of solvent types i.e: methanol and distilled water, and the concentration of $50 \mathrm{~g} \mathrm{~L}^{-1}, 100 \mathrm{~g} \mathrm{~L}^{-1}, 150$ $\mathrm{g} \mathrm{L}^{-1}, 200 \mathrm{~g} \mathrm{~L}^{-1}, 250 \mathrm{~g} \mathrm{~L}^{-1}$ with 3 replications. The result shows that Cyperus rotundus tuber flour was able to suppress weed germination of Asystasia gangetica effectively on paper material. The experiment showed a tendency that higher concentration of Cyperus rotundus tuber flour extract, higher pressing Asystasia gangetica seed germination on paper material. Both of the solvent type showed a similar effectiveness in suppress weed germination of Asystasia gangetica on paper material. Cyperus rotundus tuber flour did not effectively suppress the weed germination of Asystasia gangetica on soil material.
\end{abstract}

Keywords: Alellopathy, Asystasia gangetica, Cyperus rotundus, pre-emergence bioherbicide

\section{ABSTRAK}

Cyperus rotundus merupakan salah satu jenis gulma yang berpotensi untuk digunakan sebagai bioherbisida pratumbuh. Kandungan metabolit gulma teki Cyperus rotundus terbanyak terdapat pada bagian umbi. Penelitian ini bertujuan mengetahui keefektifan umbi teki (Cyperus rotundus) sebagai bioherbisida dalam menekan perkecambahan gulma Asystasia gangetica dan mengetahui jenis pelarut dan konsentrasi yang tepat dalam menekan perkecambahan biji gulma Asystasia gangetica. Penelitian ini dilaksanakan pada bulan Mei hingga November 2016. Penelitian ini terdiri dari 2 percobaan. Percobaan pertama merupakan pengujian ekstrak tepung umbi Cyperus rotundus terhadap perkecambahan gulma Asystasia gangetica dengan menggunakan metode uji di atas kertas. Percobaan kedua merupakan pengujian ekstrak tepung umbi teki Cyperus rotundus terhadap perkecambahan gulma Asystasia gangetica menggunakan media tanah. Percobaan pertama dan kedua menggunakan Rancangan Acak Lengkap Faktorial. Perlakuan terdiri jenis pelarut metanol dan aquades, dan konsentrasi $50 \mathrm{~g} \mathrm{~L}^{-1}, 100 \mathrm{~g} \mathrm{~L}^{-1}, 150 \mathrm{~g} \mathrm{~L}^{-1}, 200 \mathrm{~g} \mathrm{~L}^{-1}, 250 \mathrm{~g} \mathrm{~L}^{-1}$ dengan 3 ulangan. Hasil penelitian menunjukkan bahwa tepung umbi teki Cyperus rotundus mampu menekan perkecambahan gulma Asystasia gangetica pada media kertas. Hasil percobaan ini menunjukkan kecenderungan makin tinggi konsentrasi makin menekan perkecambahan gulma Asystasia gangetica pada media kertas. Kedua jenis pelarut menunjukkan keefektifan yang sama dalam menekan perkecambahan pada media kertas. Tepung umbi teki yang diberikan belum efektif dalam menekan perkecambahan gulma Asystasia gangetica pada media tanah.

Kata kunci: Alelopati, Asystasia gangetica, bioherbisida pratumbuh, Cyperus rotundus 


\section{PENDAHULUAN}

Asystasia gangetica merupakan gulma yang tumbuh pada daerah tropis dan sub tropis. Keberadaannya harus diwaspadai karena berdampak pada menurunnya keanekaragaman hayati melalui pergantian vegetasi yang dapat menurunkan ruang tumbuh tumbuhan dan hewan asli. (CRC, 2003). Asystasia gangetica merupakan salah satu gulma invasif di Indonesia dan masuk ke Indonesia diduga berasal dari Malaysia melalui Sumatera Utara. Asystasia gangetica di Indonesia saat ini tersebar di Sumatera, Jawa Barat, Jawa Tengah, serta Kalimantan (Tjitrosoedirdjo et al., 2016). Gulma ini mudah ditemukan di sekitar tepi jalan, sungai dan perkebunan (Priwiratama, 2011). Perkebunan yang diganggu khususnya perkebunan kelapa sawit (CRC, 2003). Penutupan areal kelapa sawit oleh Asystasia sp. yang berlokasi di Jambi mencapai 15,5\% (Adriadi et al., 2012) dan pada tahun 2007 di perkebunan kelapa sawit Kalimantan Tengah sebesar 16,36\% untuk lahan baru ditanami (Mubarok, 2010). Pengendalian dengan aplikasi herbisida dinilai masih belum cukup efektif.

$$
\text { Pengendalian gulma menggunakan }
$$
herbisida sintetik memberikan kerugian atau dampak negatif berupa polusi, munculnya gulma resisten serta residu yang dapat meracuni tanaman (Sukman dan Yakup, 2002). Berdasarkan hal tersebut maka saat ini diperlukan pengendalian gulma yang ramah lingkungan. Junaedi et al. (2006) menyatakan untuk mendukung budi daya ramah lingkungan salah satunya dalam pengendalian gulma dapat memanfaatkan senyawa alelopati. Palapa (2009) menyatakan Cyperus rotundus merupakan agen alelopati. Hasil serangkaian penelitian yang dilaksanakan di Institut Pertanian Bogor oleh Chozin et al. (2013), menunjukkan bahwa gulma teki Cyperus rotundus potensial untuk digunakan sebagai bioherbisida pratumbuh. Keefektifan alelopati teki sebagai herbisida karena teki mengandung senyawa aktif fenol.

Hasil uji GC-MS (Gas Chromatography Mass Spectrometry) umbi dan tajuk teki Cyperus rotundus dari tiga umur pertumbuhan terhadap senyawa fenol menunjukkan senyawa yang terkandung meliputi tocopherol; 2-furanmethanol; phenol,2,6-dimethoxy; 2-methoxy-4-vinylphenol; dan 1,2-benzenediol; kandungan metabolit terbanyak terdapat pada bagian umbi teki 3 bulan (Kusuma et al., 2017). Teki yang dihasilkan dari berbagai sumber lokasi yang berbeda memiliki keefektifan yang sama dalam menekan perkecambahan (Dewi et al., 2017). Secara umum jenis dan jumlah senyawa metabolit sekunder tumbuhan termasuk fenol dipengaruhi oleh jenis pengekstrak yang digunakan. Mu'nisa et al. (2012) melalui percobaannya dalam mengekstraksi daun cengkeh menyatakan bahwa senyawa fenol lebih efektif diekstrasi menggunakan metanol dibandingkan dengan etanol atau aquades.

Keefektifan herbisida ditentukan oleh formulasinya (Tjitrosoedirdjo et al., 1984). Kusuma (2016) melaporkan formulasi ekstrak dari teki segar konsentrasi $1,5 \mathrm{~kg} \mathrm{~L}^{-1}$ mampu menekan perkecambahan gulma Asystasia gangetica. Andhini dan Chozin (2017) melaporkan formulasi mulsa basah, mulsa kering, butiran dan tepung efektif dalam menekan perkecambahan Asystasia gangetica, tetapi formulasi yang paling efektif adalah dalam bentuk tepung. Sembodo (2010) meyatakan keunggulan dari formulasi tepung yaitu mudah diaplikasikan, mudah disimpan, harga yang relatif murah dan mudah untuk didistribusikan. Penelitian ini dilakukan untuk memperoleh informasi tentang konsentrasi dan pengekstrak yang paling baik dari tepung umbi teki.

\section{METODE PENELITIAN}

Penelitian ini dilaksanakan di Laboratorium Teknologi Benih Departemen Agronomi dan Hortikultura IPB, Laboratorium Ekofisiologi Departemen Agronomi dan Hortikulura IPB dan Laboratorium Seafast IPB. Pelaksanaan penelitian dilakukan sejak Mei hingga November 2016. Bahan yang digunakan berupa air, aquades, metanol, umbi teki Cyperus rotundus, biji Asystasia gangetica, kertas merang, tanah, amplop, alumunium foil, dan plastik. Alat yang digunakan berupa timbangan analitik, oven, blender, vacum evaporator, autoclaf, gelas ukur, botol kaca, sendok, petridish, bak semai, pipet, spreyer, saringan, corong, dan gunting.

Umbi teki Cyperus rotundus yang digunakan merupakan umbi dari tumbuhan yang telah melewati masa pembungaan. Umbi teki Cyperus rotundus dibersihkan dan dikeringkan menggunakan oven dengan suhu $60{ }^{\circ} \mathrm{C}$ selama 3 hari. Umbi teki yang telah kering dihaluskan menggunakan blender sehingga diperoleh tepung. Proses pengeringan dan pembuatan tepung mengikut Andhini (2015).

Pembuatan larutan umbi teki hasil ekstrasi dengan menggunakan aquades diperoleh dengan cara melarutkan tepung umbi teki awal ke dalam $100 \mathrm{~mL}$ aquades sesuai dengan konsentrasi yang ditentukan. Proses ekstrasi dilakukan selama 24 jam, selanjutnya disaring dan diperas. Proses ekstraksi mengikuti Delsi (2012). 
Pembuatan larutan umbi teki hasil ekstraksi dengan menggunakan metanol diperoleh dengan cara melarutkan tepung umbi teki awal ke dalam metanol dengan perbandingan tepung dan metanol 1:7,5 (maserasi) dan 1:2,5

(remaserasi). Maserasi dilakukan selama $5 \times 24$ jam, remaserasi dilakukan selama $2 \times 24$ jam (Astarina et al., 2013). Larutan hasil maserasi selanjutnya disaring sehingga diperoleh filtrat. Filtrat tersebut diuapkan meggunakan vacuum evaporator hingga memperoleh rendemen berupa ekstrak kering. Larutan diperoleh dengan melarutkan sejumlah ekstrak kering ke dalam 100 $\mathrm{mL}$ aquades sesuai dengan konsentrasi yang telah ditentukan.

Percobaan pertama menggunakan Rancangan Acak Lengkap (RAL) dua faktor. Faktor pertama yaitu jenis pelarut (metanol dan aquades), faktor kedua konsentrasi $\left(50 \mathrm{~g} \mathrm{~L}^{-1}, 100\right.$ $\left.\mathrm{g} \mathrm{L}^{-1}, 150 \mathrm{~g} \mathrm{~L}^{-1}, 200 \mathrm{~g} \mathrm{~L}^{-1}, 250 \mathrm{~g} \mathrm{~L}^{-1}\right)$. Kontrol digunakan sebagai pembanding untuk menilai keefektifan perlakuan. Media yang digunakan adalah kertas merang. Kertas merang dibasahi dengan larutan sesuai konsentrasi yang telah ditentukan hingga kondisi lembap $(5 \mathrm{~mL})$. Biji gulma disusun sebanyak 25 biji setiap petridish untuk setiap perlakuan dengan 3 ulangan. Perkecambahan menggunakan alat seed germinator. Pengamatan perkecambahan dilakukan selama 14 hari. Pengamatan yang dilakukan berupa perkecambah, kecepatan tumbuh kecambah (\% etmal $\left.{ }^{-1}\right)$, panjang plumula dan panjang radikula. Data yang diperoleh dianalisis menggunakan uji $\mathrm{F}$, apabila perlakuan menunjukkan pengaruh nyata, dilakukan uji lanjut menggunakan Duncan's multiple range test (DMRT) dengan taraf 5\%.

$$
\text { Percobaan kedua menggunakan }
$$

Rancangan Acak Lengkap (RAL) dua faktor. Faktor pertama yaitu jenis pelarut (metanol dan aquades), faktor kedua yaitu konsentrasi $\left(50 \mathrm{~g} \mathrm{~L}^{-1}\right.$, $100 \mathrm{~g} \mathrm{~L}^{-1}, 150 \mathrm{~g} \mathrm{~L}^{-1}, 200 \mathrm{~g} \mathrm{~L}^{-1}$, dan $250 \mathrm{~g} \mathrm{~L}^{-1}$ ). Kontrol digunakan sebagai pembanding untuk menilai efektivitas perlakuan. Media yang digunakan adalah tanah. Sterilisasi tanah menggunakan autoclaf pada suhu $121^{\circ} \mathrm{C}$ selama 20 menit diulang 3 kali. Metode sterilisasi tanah mengikuti Cahyani (2009). Biji gulma ditanam dalam bak semai ukuran $24,5 \mathrm{~cm}$ x $19,5 \mathrm{~cm} \times 4,5$ $\mathrm{cm}$ sebanyak 25 biji per bak semai untuk setiap perlakuan dengan 3 ulangan. Biji ditanam diatas permukaan tanah. Aplikasi dilakukan hanya sekali saat awal penanaman atau 0 hari setelah semai (HSS) yaitu $8 \mathrm{~mL}$ per bak semai. Pengamatan perkecambahan dilakukan selama 21 hari. Pengamatan yang dilakukan berupa perkecambah, kecepatan tumbuh kecambah $\left(\%\right.$ etmal $\left.^{-1}\right)$, panjang plumula dan panjang radikula. Data yang diperoleh dianalisis menggunakan uji $\mathrm{F}$, apabila perlakuan menunjukkan pengaruh nyata, dilakukan uji lanjut menggunakan duncan's multiple range test (DMRT) dengan taraf 5\%.

\section{HASIL DAN PEMBAHASAN}

\section{Percobaan 1 Perkecambahan pada Media Kertas}

Hasil percobaan pada media kertas merang menunjukkan perlakuan larutan umbi teki Cyperus rotundus efektif dalam menekan daya berkecambah gulma Asystasia gangetica. Larutan umbi teki konsentrasi $50 \mathrm{~g} \mathrm{~L}^{-1}$ dapat menekan daya berkecambah sebesar $54,77 \%$ dan konsentrasi $250 \mathrm{~g} \mathrm{~L}^{-1}$ sebesar 95,23\%. Penekanan daya berkecambah gulma Asystasia gangetica meningkat seiring dengan meningkatnya konsentrasi yang diberikan, menggunakan jenis pelarut metanol maupun dengan jenis pelarut aquades (Gambar 1). Kedua jenis pelarut tersebut pada konsentrasi yang sama menunjukkan keefektifan yang tidak berbeda dalam menekan daya berkecambah biji gulma Asystasia gangetica. Informasi pada Gambar 1 diperkuat oleh hasil pengujian statistika pada Tabel 1 yang menunjukkan tidak ada perbedaan nyata antara kedua pelarut tersebut.

Penekanan daya berkecambah gulma Asystasia gangetica diduga disebabkan oleh senyawa metabolit yang terkandung di dalam umbi teki Cyperus rotundus. Kusuma et al. (2017) melaporkan senyawa metabolit yang terkandung dalam umbi teki diantaranya merupakan senyawa fenol berupa 2-furanmethanol. 2-furanmethanol merupakan nama lain dari furfuryl alcohol (IFC, 2015), merupakan senyawa kimia yang dapat diperoleh dari hidrogenasi senyawa furfural, jika dihidrogenasi lebih lanjut maka akan menghasilkan senyawa tetrahidrofurfuril alcohol (Villaverde et al., 2013). Tetrahidrofurfuril alcohol digunakan sebagai herbisida (PENNAKEM, 2008).

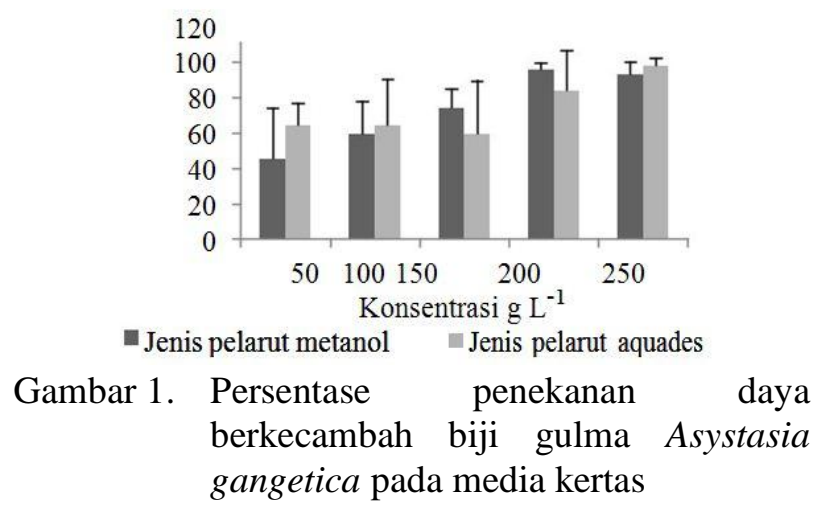


Daya berkecambah biji gulma Asystasia gangetica pada berbagai konsentrasi dan jenis pelarut ditunjukan oleh Tabel 1. Peubah daya berkecambah dipengaruhi secara nyata oleh kosentrasi tetapi tidak oleh jenis pelarut dan interaksinya. Rata-rata daya berkecambah biji gulma Asystasia gangetica pada konsentrasi $50 \mathrm{~g}$ $\mathrm{L}^{-1}$ hingga $150 \mathrm{~g} \mathrm{~L}^{-1}$ berkisar antara $18,67 \%$ hingga $25,33 \%$, lebih besar dan berbeda nyata dengan perlakuan konsentrasi $200 \mathrm{~g} \mathrm{~L}^{-1}$ dan konsentrasi $250 \mathrm{~g} \mathrm{~L}^{-1}$. Rata-rata perkecambahan pada konsentrasi $200 \mathrm{~g} \mathrm{~L}^{-1}$ yaitu $6,00 \%$ dan konsentrasi $250 \mathrm{~g} \mathrm{~L}^{-1}$ yaitu 2,67\%. Gambar 2 menunjukkan bahwa makin tinggi konsentrasi maka makin rendah daya berkecambah.

Konsentrasi berpengaruh nyata terhadap kecepatan tumbuh kecambah Asystasia gangetica tetapi jenis pelarut dan interaksinya tidak. Ratarata kecepatan tumbuh kecambah Asystasia gangetica pada konsentrasi $50 \mathrm{~g} \mathrm{~L} \mathrm{~L}^{-1}$ dan konsentrasi $100 \mathrm{~g} \mathrm{~L}^{-1}$ adalah $2,91 \%$ etmal $^{-1}$ dan $2,09 \%$ etmal $^{-1}$, lebih tinggi dan berbeda nyata dengan konsentrasi $200 \mathrm{~g} \mathrm{~L}^{-1}$ dan konsentrasi 250 $\mathrm{g} \mathrm{L}^{-1}$ yang nilainya $0,48 \%$ etmal $^{-1}$ dan $0,23 \%$ etmal $^{-1}$.

Hasil sidik ragam menunjukkan jenis pelarut, konsentrasi dan interaksi tidak berpengaruh nyata terhadap panjang plumula kecambah Asystasia gangetica (Tabel 1). Ratarata panjang plumula pada pelarut metanol yaitu $0,45 \mathrm{~cm}$ lebih pendek tetapi tidak berbeda nyata dibandingkan dengan perlakuan jenis pelarut aquades $(0,68 \mathrm{~cm})$. Rata-rata plumula terpanjang diperoleh pada konsentrasi $50 \mathrm{~g} \mathrm{~L}^{-1}(0,87 \mathrm{~cm})$ namun tidak berbeda nyata terhadap perlakuan konsentrasi lainnya yang berkisar $0,22 \mathrm{~cm}$ hingga $0,74 \mathrm{~cm}$.

Informasi pada Tabel 1 menunjukkan bahwa panjang radikula dipengaruhi secara nyata oleh konsentrasi tetapi tidak oleh jenis pelarut dan interaksinya. Rata-rata panjang radikula pada konsentrasi $50 \mathrm{~g} \mathrm{~L}^{-1}$ adalah 2,61 $\mathrm{cm}$ lebih panjang dan berbeda nyata dibandingkan dengan konsentrasi lainnya. Rata-rata panjang radikula terpendek yaitu $0,38 \mathrm{~cm}$ diperoleh konsentrasi 250 $\mathrm{g} \mathrm{L}^{-1}$.

Tabel 1. Rata-rata perkecambahan, kecepatan tumbuh, panjang plumula 14 HSS dan panjang radikula 14 HSS pada media kertas.

\begin{tabular}{|c|c|c|c|c|}
\hline \multirow[b]{2}{*}{ Perlakuan } & \multicolumn{4}{|c|}{ Asystasia gangetica } \\
\hline & $\begin{array}{c}\text { Daya Berkecambah } \\
(\%)\end{array}$ & $\begin{array}{c}\text { Kecepatan tumbuh (\% } \\
\left.\text { etmal }^{-1}\right)\end{array}$ & $\begin{array}{l}\text { Plumula 14 HSS } \\
(\mathrm{cm})\end{array}$ & $\begin{array}{c}\text { Radikula 14 HSS } \\
(\mathrm{cm})\end{array}$ \\
\hline Kontrol & 56,00 & 9,23 & 3,06 & 2,90 \\
\hline $\begin{array}{l}\text { Jenis pelarut } \\
(\mathrm{J})\end{array}$ & & & & \\
\hline Metanol & 14,93 & 1,51 & 0,45 & 1,04 \\
\hline Aquades & 14,67 & 1,43 & 0,68 & 1,43 \\
\hline Uji F & tn & tn & tn & tn \\
\hline $\begin{array}{l}\text { Konsentrasi } \\
(\mathrm{K})\end{array}$ & & & & \\
\hline $50 \mathrm{~g} \mathrm{~L}^{-1}$ & $25,33 \mathrm{a}$ & $2,91 \mathrm{a}$ & 0,87 & $2,61 \mathrm{a}$ \\
\hline $100 \mathrm{~g} \mathrm{~L}^{-1}$ & $21,33 a$ & $2,09 \mathrm{a}$ & 0,74 & $1,54 \mathrm{~b}$ \\
\hline $150 \mathrm{~g} \mathrm{~L}^{-1}$ & $18,67 \mathrm{ab}$ & $1,64 \mathrm{ab}$ & 0,51 & $0,81 b c$ \\
\hline $200 \mathrm{~g} \mathrm{~L}^{-1}$ & $6,00 \mathrm{bc}$ & $0,48 b$ & 0,58 & $0,96 b c$ \\
\hline $250 \mathrm{~g} \mathrm{~L}^{-1}$ & $2,67 \mathrm{c}$ & $0,23 b$ & 0,22 & $0,38 \mathrm{c}$ \\
\hline Uji F & ** & ** & tn & ** \\
\hline Interaksi JxK & & & & \\
\hline Uji F & tn & tn & tn & tn \\
\hline
\end{tabular}

Keterangan: Angka yang diikuti oleh huruf yang berbeda pada kolom yang sama menunjukkan berbeda nyata berdasarkan uji DMRT taraf 5\%, tn: tidak berpengaruh nyata pada uji $\mathrm{F} 5 \%$, *: berpengaruh nyata pada uji $\mathrm{F} 5 \%$, **: berpengaruh sangat nyata pada taraf $1 \%$, HSS: hari setelah semai. 


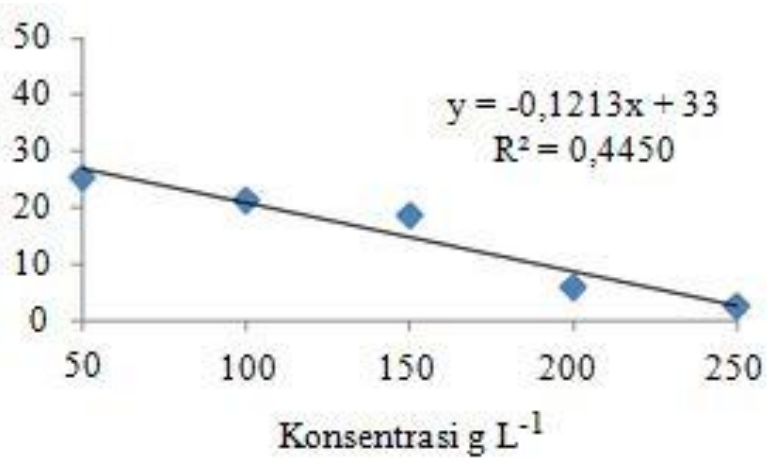

Gambar 2. Regresi antara konsentrasi dan daya berkecambah gulma Asystasia gangetica pada media kertas

Hasil penelitian ini menunjukkan bahwa tepung umbi teki Cyperus rotundus efektif dalam menekan perkecambahan biji gulma Asystasia gangetica. Terdapat indikasi makin tinggi konsetrasi maka makin besar penekanannya. Hal ini memperkuat penelitian terdahulu yang telah dilakukan oleh Delsi (2012), Andhini dan Chozin (2017) dan Kusuma et al. (2017).
Percobaan 2 Perkecambahan pada Media Tanah

Penyemprotan larutan umbi teki Cyperus rotundus tidak efektif dalam menekan daya berkecambah biji gulma Asystasia gangetica pada media tanah. Gambar 4 menunjukkan penyemprotan larutan umbi teki dengan pelarut metanol maupun aquades, konsentrasi $50 \mathrm{~g} \mathrm{~L}^{-1}$ hingga $250 \mathrm{~g} \mathrm{~L}^{-1}$ hanya mampu menekan daya berkecambah kurang dari $40 \%$. Hal tersebut menunjukkan hasil yang berbeda dengan percobaan yang telah dilakukan menggunakan media kertas.

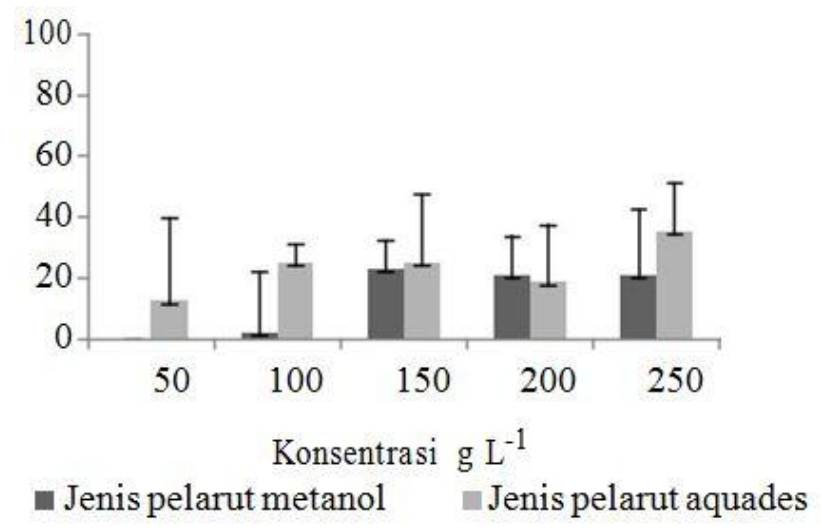

Gambar 3. Persentase penekanan daya berkecambah biji gulma Asystasia gangetica pada media tanah

Tabel 2 menunjukkan hasil sidik ragam perlakuan jenis pelarut, konsentrasi serta interaksi tidak berpengaruh nyata terhadap seluruh peubah yang diamati kecuali pada peubah kecepatan tumbuh kecambah biji gulma Asystasia gagnetica. Walaupun demikian, rata-rata daya berkecambah biji Asystasia gangetica pada konsentrasi $50 \mathrm{~g} \mathrm{~L}^{-1}$ hingga $250 \mathrm{~g} \mathrm{~L}^{-1}$ berkisar antara $46,00 \%$ hingga $60,00 \%$, sedikit lebih rendah dibandingkan dengan perlakuan kontrol (64\%).

Hasil sidik ragam menunjukkan bahwa perlakuan jenis pelarut dan konsentrasi berpengaruh nyata terhadap kecepatan tumbuh kecambah Asystasia gangetica, tetapi interaksi tidak berpengaruh nyata (Tabel 2). Rata-rata kecepatan tumbuh kecambah pada jenis pelarut aquades yaitu $4,38 \%$ etmal $^{-1}$ lebih rendah dan berbeda nyata dengan jenis pelarut metanol $\left(5,43 \%\right.$ etmal $\left.^{-1}\right)$, tetapi kecepatan tumbuh kecambah jenis pelarut metanol masih lebih rendah dibandingkan dengan kontrol $(9,63 \%$ etmal $\left.^{-1}\right)$. Rata-rata kecepatan tumbuh kecambah Asystasia gangetica konsentrasi $50 \mathrm{~g} \mathrm{~L}^{-1}$ yaitu $6,77 \%$ etmal $^{-1}$, lebih rendah dibandingkan dengan kontrol $\left(9,63 \% \mathrm{etmal}^{-1}\right)$. Meskipun demikian ratarata kecepatan tumbuh kecambah konsentrasi $50 \mathrm{~g}$ $\mathrm{L}^{-1}$ lebih tinggi dan berbeda nyata dengan konsentrasi lainnya yang berkisar $3,71 \%$ etmal $^{-1}$ hingga $5,16 \%$ etmal $^{-1}$. 
Tabel 2. Rata-rata perkecambahan, kecepatan tumbuh gulma, panjang plumula 14 HSS dan panjang radikula 14 HSS media tanah.

\begin{tabular}{|c|c|c|c|c|}
\hline \multirow[b]{2}{*}{ Perlakuan } & \multicolumn{4}{|c|}{ Asystasia gangetica } \\
\hline & $\begin{array}{c}\text { Daya Berkecambah } \\
(\%)\end{array}$ & $\begin{array}{c}\text { Kecepatan tumbuh (\% } \\
\text { etmal-1) }\end{array}$ & $\begin{array}{l}\text { Plumula 14 HSS } \\
(\mathrm{cm})\end{array}$ & $\begin{array}{l}\text { Radikula 14 HSS } \\
(\mathrm{cm})\end{array}$ \\
\hline $\begin{array}{l}\text { Kontrol } \\
\text { Jenis pelarut } \\
\text { (J) }\end{array}$ & 64,00 & 9,63 & 2,43 & 4,18 \\
\hline Metanol & 55,47 & $5,43 a$ & 1,90 & 4,16 \\
\hline Aquades & 49,07 & $4,38 \mathrm{~b}$ & 1,37 & 3,39 \\
\hline $\begin{array}{l}\text { Uji F } \\
\text { Konsentrasi } \\
\text { (K) }\end{array}$ & tn & $*$ & tn & tn \\
\hline $50 \mathrm{~g} \mathrm{~L}^{-1}$ & 60,00 & $6,77 \mathrm{a}$ & 2,15 & 4,49 \\
\hline $100 \mathrm{~g} \mathrm{~L}^{-1}$ & 55,33 & $5,16 \mathrm{~b}$ & 1,98 & 4,44 \\
\hline $150 \mathrm{~g} \mathrm{~L}^{-1}$ & 48,67 & $4,53 b$ & 1,38 & 3,74 \\
\hline $200 \mathrm{~g} \mathrm{~L}^{-1}$ & 51,33 & $4,35 b$ & 1,50 & 3,30 \\
\hline $250 \mathrm{~g} \mathrm{~L}^{-1}$ & 46,00 & $3,71 \mathrm{~b}$ & 1,18 & 2,91 \\
\hline $\begin{array}{l}\text { Uji F } \\
\text { Interaksi JxK }\end{array}$ & tn & $* *$ & tn & tn \\
\hline Uji F & tn & tn & tn & tn \\
\hline
\end{tabular}

Keterangan: Angka yang diikuti oleh huruf yang berbeda pada kolom yang sama menunjukkan berbeda nyata berdasarkan uji DMRT taraf 5\%, tn: tidak berberpengaruh nyata pada uji $\mathrm{F} 5 \%$, *: berpengaruh nyata pada uji $\mathrm{F} 5 \%$, **: berpengaruh sangat nyata pada taraf $1 \%$, HSS: hari setelah semai.

Kedua percobaan ini mengindikasikan perlakuan penyemprotan larutan tepung umbi teki efektif menekan perkecambahan biji gulma Asystasia gangetica pada pengujian menggunakan media kertas, tetapi tidak efektif pada pengujian menggunakan media tanah. Hal tersebut tidak berbeda dengan penelitian yang dilakukan oleh Setyowati et al. (2001) dalam pengujian formulasi dan cara aplikasi ekstrak teki menggunakan media pasir sungai bahwa ekstrak umbi teki berbagai formulasi tidak berpengaruh terhadap seluruh variabel perkecambahan gulma Melochia corchorifolia dan Mimosa invisa kecuali pada panjang akar Mimosa invisa.

Keefektifan larutan umbi teki yang diaplikasikan sebagai herbisida pratumbuh pada percobaan menggunakan media tanah diduga dipengaruhi oleh kemampuan tanah dalam adsorpsi larutan tepung umbi teki. Andhini dan Chozin (2017) dalam pengujian keefektifan berbagai konsentrasi ekstrak teki pada berbagai jenis tanah melaporkan bahwa perkecambahan gulma Asystasia gangetica terendah yaitu terjadi pada jenis tanah kuarsa (kandungan pasir lebih tinggi) dan perkecambahan tertinggi terjadi pada jenis tanah regosol. Hal tersebut diduga keefektifan ekstrak teki Cyperus rotundus dalam menekan perkecambahan gulma Asystasia gangetica dipengaruhi oleh adsorpsi kandungan liat tanah. Muktamar (2003) menyatakan adsorpsi koloid tanah mempengaruhi perilaku herbisida.

Keefektifan larutan tepung umbi teki Cyperus rotundus selain diduga dipengaruhi oleh kemampuan absorpsi koloid tanah diduga pula oleh waktu aplikasi dan waktu perkecambahan biji gulma. Penyemprotan larutan tepung umbi teki Cyperus rotundus dilakukan pada saat tanam (0 HSS) dan biji Asystasia gangetica pada percobaan media tanah mulai berkecambah pada 2 HSS. Hal tersebut diperkirakan larutan terlebih dahulu terabsorpsi oleh kolid tanah karena waktu aplikasi yang tidak sesuai dengan stadia perkecambahan. Oleh karena itu diperlukan penelitian lebih lanjut tentang waktu penyemprotan yang sesuai.

\section{KESIMPULAN}

Hasil penelitian ini menunjukkan bahwa kedua jenis pelarut menunjukkan keefektifan yang sama dalam menekan perkecambahan biji gulma Asystasia gagnetica pada media kertas. Tepung umbi teki Cyperus rotundus pada konsentrasi $50 \mathrm{~g} \mathrm{~L}^{-1}$ dinilai cukup efektif dalam menekan perkecambahan biji gulma Asystasia gangetica pada media kertas, tetapi tidak efektif pada pengujian menggunakan media tanah. Terdapat indikasi makin tinggi konsentrasi maka makin besar penekanan perkecambahan. 


\section{DAFTAR PUSTAKA}

Adriadi, A. Chairul, Solfiyeni. 2012. Analisis vegetasi gulma pada perkebunan kelapa sawit (Elaeis quineensis jacq.) di Kilangan, Muaro Bulian, Batang Hari. Jurnal Biologi Universitas Andalas 1(2): 108-115.

Andhini, M., M. A. Chozin. 2017. Keefektifan allelopati teki (Cyperus rotundus L.) terhadap penekanan perkecambahan biji Asystasia gangetica (L.) T. Andreson pada berbagai jenis tanah. Bulletin Agrohorti 4 (2): 180-186.

Astarina, N.W.G., K.W. Astuti, N.K Warditiani. 2013. Skrining fitokimia ekstrak metanol rimpang bangle (Zingiber pupureum Roxb.). Jurnal Farmasi Udayana 2(4): 17.

Chozin, M.A., Y. Delsi, R. Saputra, Syarifi, S.A. Arifin, S. Zaman S. 2013. Some studies on allelopatic potential of Cyperus rotundus L. Dalam: Bakar B.H., Kurniadie D, Tjitrosoedirdjo S., (Eds). The Role of Weed Science in Supporting Food Security by 2020. Proceedings of 24th Asian-Pasific Weed Science Society Conference; Bandung 22-25 Oktober 2013.

[CRC] Cooperative Research Centre for Australian Weed Management. 2003. Weed management guide: Asystasia gangetica ssp. micrantha. [Internet] [diunduh 2015 Desember 17] tersedia pada

https://www.environment.gov.au/biodiver sity/invasive/

weeds/publications/guidelines/alert/pubs/ a-gangetica.pdf.

Delsi, Y. 2012. Studi alelopati teki (Cyperus rotundus L.) sebagai bioherbisida untuk pengendalian gulma berdaun lebar. Tesis. Institut Pertanian Bogor. Bogor.

Dewi, S.A., M. A. Chozin, D. Guntoro 2017. Identifikasi senyawa fenol beberapa asesi teki (Cyperus rotundus L.) serta pengaruhnya terhadap perkecambahan biji Borreria alata (Aubl.) DC. Jurnal Agronomi Indonesia 45 (1): 93-99.
[IFC] International Furan Chemicals B.V. 2015. Furfuryl Alcohol. [Internet] [diunduh 2017 Februari 12] tersedia pada http:// www.furan.com/_resources/downloads/IF C\%20MSDS\%20Furfural\%20Alcohol\%2 0English.pdf.

Junaedi, A., M. A. Chozin, Kim K.H. 2006. Perkembangan terkini kajian alelopati. Jurnal Hayati 13(2):79-84.

Kusuma, A.V.C., M. A. Chozin, D. Guntoro 2016. Senyawa fenol dari tajuk dan umbi teki (Cyperus rotundus L.) pada berbagai umur serta pengaruhnya terhadap perkecambahan gulma berdaun lebar. Jurnal Agronomi Indonesia 45(1): 100107.

Mubarok H. 2010. Studi pengelolaan gulma di Perkebunan Kelapa Sawit Sekunyir Estate, PT. Indoruba, Trengah, Manimas Plantation, Kalimantan Tengah. Skripsi. Institut Pertanian Bogor. Bogor.

Muktamar Z., Faryani S. dan Setyowati N. 2003. Adsorpsi paraquat oleh bahan mineral ultisol dan entisol pada berbagai konsentrasi. JIPI. 5(2): 40-47.

Mu'nisa, A., T. Wresdiyati, T. Kusumorini, W. Manalu. 2012. Aktivitas antioksidan ekstrak daun cengkeh (Antioxidant activity of clove leave extract). Jurnal Veteriner 13(3): 272-277

Palapa, T.M. 2009. Senyawa alelopati teki (Cyperus rotudus) dan alang-alang (Imperata cylindrica) sebagai penghambat pertumbuhan bayam duri (Amarathus spinosus). AGRITEK. 17(6): 1155-1162.

PENNAKEM. 2008. Tetrahydrofurfuryl alcohol. [Internet] [diunduh 2016 November 29] tersedia pada http://www.pennakem.com/pdfs/OTHER/ THFAgreenTDS120aF1004.Pdf.

Priwiratama, H. 2011. Informasi pengganggu tanaman Asystasia gangetica (L.) subsp. Micrantha (Nees). Pusat Penelitian Kelapa Sawit G(1): 1-2.

Sembodo, D.R.J. 2010. Gulma dan Pengelolaannya. Graha Ilmu, Yogyakarta. 
Setyowati, N., E. Supijono. 2001. Efikasi alelopati teki formulasi cairan terhadap gulma Mimosa invisa dan melochia corchorifolin. JIPI. 3(1): 16-24.

Sukman, Y., Yakup. 2002. Gulma dan Teknik Pengendaliannya. PT Raja Grafindo Persada, Jakarta.
Tjitrosoedirdjo, S., I.H. Utomo, Wiroatmodjo. 1984. Pengelolaan Gulma di Perkebunan. Gramedia, Jakarta.

Villaverde, M.M., N.M. Bertero, T.F. Garetto, A.J. Marchi. 2013. Selective LiquidphSe hydrogenation of furfural to furfuryl alchol over Cu-based catalyst. Catalysis today 213: 87-92 